\title{
Proteomics of methyl jasmonate induced defense response in maize leaves against Asian corn borer
}

\author{
Yi Tong Zhang ${ }^{1,3+}$, Yu Liang Zhang ${ }^{2+}$, Si Xue Chen ${ }^{1,4}$, Guo Hua Yin ${ }^{2,5^{*}}$, Ze Zhong Yang ${ }^{1,6}$, Samantha Lee ${ }^{5}$, \\ Chun Guang Liu ${ }^{1,7}$, Dan Dan Zhao ${ }^{1,7}$, Yu Kun Ma ${ }^{1,7}$, Fu Qiang Song ${ }^{1,7}$, Joan W Bennett ${ }^{5}$ and Feng Shan Yang ${ }^{1,7^{*}}$
}

\begin{abstract}
Background: Jasmonic acid (JA) and methyl jasmonate (MeJA) regulate plant development, resistance to stress, and insect attack by inducing specific gene expression. However, little is known about the mechanism of plant defense against herbivore attack at a protein level. Using a high-resolution 2-D gel, we identified 62 MeJA-responsive proteins and measured protein expression level changes.

Results: Among these 62 proteins, 43 proteins levels were increased while 11 proteins were decreased. We also found eight proteins uniquely expressed in response to MeJA treatment. Data are available via ProteomeXchange with identifier PXD001793. The proteins identified in this study have important biological functions including photosynthesis and energy related proteins (38.4\%), protein folding, degradation and regulated proteins (15.0\%), stress and defense regulated proteins (11.7\%), and redox-responsive proteins (8.3\%). The expression levels of four important genes were determined by qRT-PCR analysis. The expression levels of these proteins did not correlate well with their translation levels. To test the defense functions of the differentially expressed proteins, expression vectors of four protein coding genes were constructed to express in-fusion proteins in E. coli. The expressed proteins were used to feed Ostrinia furnacalis, the Asian corn borer (ACB). Our results demonstrated that the recombinant proteins of pathogenesis-related protein 1 (PR1) and thioredoxin M-type, chloroplastic precursor (TRXM) showed the significant inhibition on the development of larvae and pupae.
\end{abstract}

Conclusions: We found MeJA could not only induce plant defense mechanisms to insects, it also enhanced toxic protein production that potentially can be used for bio-control of ACB.

Keywords: Maize, 2-DE, Mass spectrometry, Methyl jasmonate, qRT-PCR, Asian corn borer, Bio-control

\section{Background}

The plant hormone jasmonic acid (JA) is involved in diverse developmental processes and defense responses to abiotic and biotic stresses. JA affects various stages of plant development including germination, root growth, tendril coiling, fertility, fruit ripening, tuberization, and senescence [1-4]. Methyl jasmonate (MeJA), the volatile form of JA, has been widely used to study jasmonate signaling pathways and mechanisms of plant defense. MeJA activates a signaling cascade of plant cell membrane

\footnotetext{
*Correspondence: guohuayin1997@gmail.com; yangfengshan@hlju.edu.cn ${ }^{\dagger}$ Equal contributors

${ }^{2}$ Key Laboratory of Biology and Genetic Resources of Tropical Crops, Ministry of Agriculture, Institute of Tropical Bioscience and Biotechnology, Chinese Academy of Tropical Agricultural Sciences, Haikou, Hainan 571101, China 'Key Laboratory of Molecular Biology of Heilongjiang Province, College of Life Sciences, Heilongjiang University, Harbin 150080, China

Full list of author information is available at the end of the article
}

genes. Following activation, the expression levels of defensive genes, such as proteinase inhibitors and pathogenesis-related (PR) proteins, change in order to regulate plant defense and immune responses [5].

With recent advances in genomic technologies, many jasmonate-responsive genes have been identified including those involved in jasmonate biosynthesis, secondary metabolism, and signal conduction and gene activation pathways [6]. MeJA-mediated signaling pathways and cellular responses can be researched using functional genomics and bioinformatics approaches. Most of the earlier studies examining the role of JA or MeJA in Arabidopsis, tomato, and tobacco employed microarray technology [7-10]. Studies have shown significant changes in the expression levels of induced genes. These studies

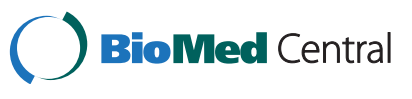

(c) 2015 Zhang et al.; licensee BioMed Central. This is an Open Access article distributed under the terms of the Creative Commons Attribution License (http://creativecommons.org/licenses/by/4.0), which permits unrestricted use, distribution, and reproduction in any medium, provided the original work is properly credited. The Creative Commons Public Domain Dedication waiver (http://creativecommons.org/publicdomain/zero/1.0/) applies to the data made available in this article, unless otherwise stated. 
have pushed the research toward the functional analysis of JA-response genes; however, due to the limitations of the microarray approach, the direct functions of JA-induced genes are unable to be determined.

The availability of genome sequences of many plant species and high-throughput technologies such as proteomics have facilitated a better understanding of the role of MeJA and its regulatory networks in plants. These later studies have been conducted in Arabidopsis, rice and wheat $[11,12]$. For example, the expression of JA-induced PR proteins and cellular protectant proteins in rice leaves were shown along with suppression of ribulose1,5-bisphosphate carboxylase/oxygenase (RuBisCO), and exogenous application of JA induced the expression of several defense and stress-related genes [13,14]. Similarly, exogenous MeJA significantly enhanced disease resistance in wheat and showed significant increase of the expression of PR genes [15].

To date, there is limited research examining the effects of MeJA on signal pathways and cellular responses in maize. As a global crop, maize quality and yield is affected by environmental conditions and pathogen exposures. Previous studies report that exogenous application of MeJA induced physiological and molecular changes leading to increased resistance to pathogens and other stressors. Although these studies provide some insight to MeJA function in maize, there is a need to examine both the expression of genes and proteins since mRNA levels are not always consistent with protein levels due to post-transcriptional, translational, and post-translational regulatory activities. In order to adequately study the molecular basis of MeJA-induced changes in maize, we examined both gene and protein expressions. Recent proteomics studies in maize focus on drought [16], light [17], and temperature stresses [18]; however, MeJA responses in maize using proteomic approaches have not been reported.

The aim of the present study is to identify proteins and genes induced by MeJA and to determine how the protein levels are regulated by MeJA. Using proteomics and qRT-PCR technologies, we identified differentially expressed genes and proteins. We present the correlation between differentially expressed proteins and genes induced by MeJA involved in various cellular functions.

\section{Results}

\section{Plant proteins under MeJA treatment}

In this study, to determine the best induction conditions of exogenous application of MeJA, four time points (3, 6,12 , and $24 \mathrm{~h}$ ) and four concentrations (50, 100, 225, and $450 \mu \mathrm{M}$ ) were tested. Total proteins of each group were analyzed using SDS-PAGE and the protein profiles were compared. The mass spectrometry proteomics data have been deposited to the ProteomeXchange Consortium
[19] via the PRIDE partner repository with the dataset identifier PXD001793. The total protein concentration in maize reached the highest concentration at $225 \mu \mathrm{M}$ of MeJA for 12 hours (Figure 1).

\section{The effects of feeding $A C B$ larvae and adults with MeJA-treated maize}

To evaluate the effects of MeJA on different larval stages of Ostrinia furnacalis, commonly known as the Asian corn borer (ACB), we inspected the mortality rate of larvae fed on corn leaves treated with different concentrations of MeJA. Summarized in Figure 2, the mortality rates of larvae fed on leaves treated with different concentrations of MeJA were all higher than the controls. Increasing concentrations of MeJA caused the mortality rate of larvae to increase and reached its highest level at the concentration of $225 \mu \mathrm{M}$. There was a decrease in the mortality rate at the concentration of $450 \mu \mathrm{M}$. The $3^{\text {rd }}$ stage larvae were significantly affected by MeJA compared to the other stages of larvae $\left(1^{\text {st }}, 2^{\text {nd }}\right.$, and $\left.4^{\text {th }}\right)$. Thus, we concluded that the ACB were significantly affected at $225 \mu \mathrm{M}$ of MeJA $(P<0.05)$.

We also assayed the effects of MeJA on the developmental duration of different larval stages of the ACB. With increasing concentrations of MeJA, the number of days spent in different stages of development increased. Although $1^{\text {st }}$ instar larvae were not affected significantly, total duration of other stages of larvae $\left(2^{\text {nd }}, 3^{\text {rd }}\right.$, and $\left.4^{\text {th }}\right)$ were significantly delayed by 225 and $450 \mu \mathrm{M}$ of MeJA $(P<0.05)$. Compared to controls, $2^{\text {nd }}, 3^{\text {rd }}$, and $4^{\text {th }}$ instar larvae exposed to $225 \mu \mathrm{M}$ of MeJA were developmentally delayed by $24 \%, 22 \%$, and $75 \%$, respectively. The $5^{\text {th }}$ instar larvae were also significantly delayed at 100 and $225 \mu \mathrm{M}$ of MeJA $(P<0.05)$ (Table 1$)$. In summary, the differences between the treated and control groups were significant at $225 \mu \mathrm{M}$ of MeJA for 12 hours.

The adult life span and average number of eggs produced by the female per day also were significantly affected by MeJA. The adult life span of the treatment group was shortened by $0.23 \sim 1.33$ days compared to control group. There was a decrease in the number of eggs with increased concentrations of MeJA with a significant decrease in the number of eggs produced by female at 100, 225, and $450 \mu \mathrm{M}$ (Table 2).

We examined the effects on insect growth and development of ACB larvae fed on maize treated with different concentrations of exogenous MeJA. The growth and development of ACB larvae were significantly inhibited with MeJA. Compared to the control group, the weight of larvae treated with 225 and $450 \mu \mathrm{M}$ of MeJA was significantly decreased by $3.29 \sim 6.86 \mathrm{mg}(28.3 \% \sim 59.1 \%)$, and the weight of pupae significantly decreased $(P<0.05)$ by $4.87 \mathrm{mg}$ (Figure $3 \mathrm{AB}$ ). Many of the pupae fed by maize leaves treated by $225 \mu \mathrm{M}$ of MeJA for 12 hours were abnormal (Figure 3C). 


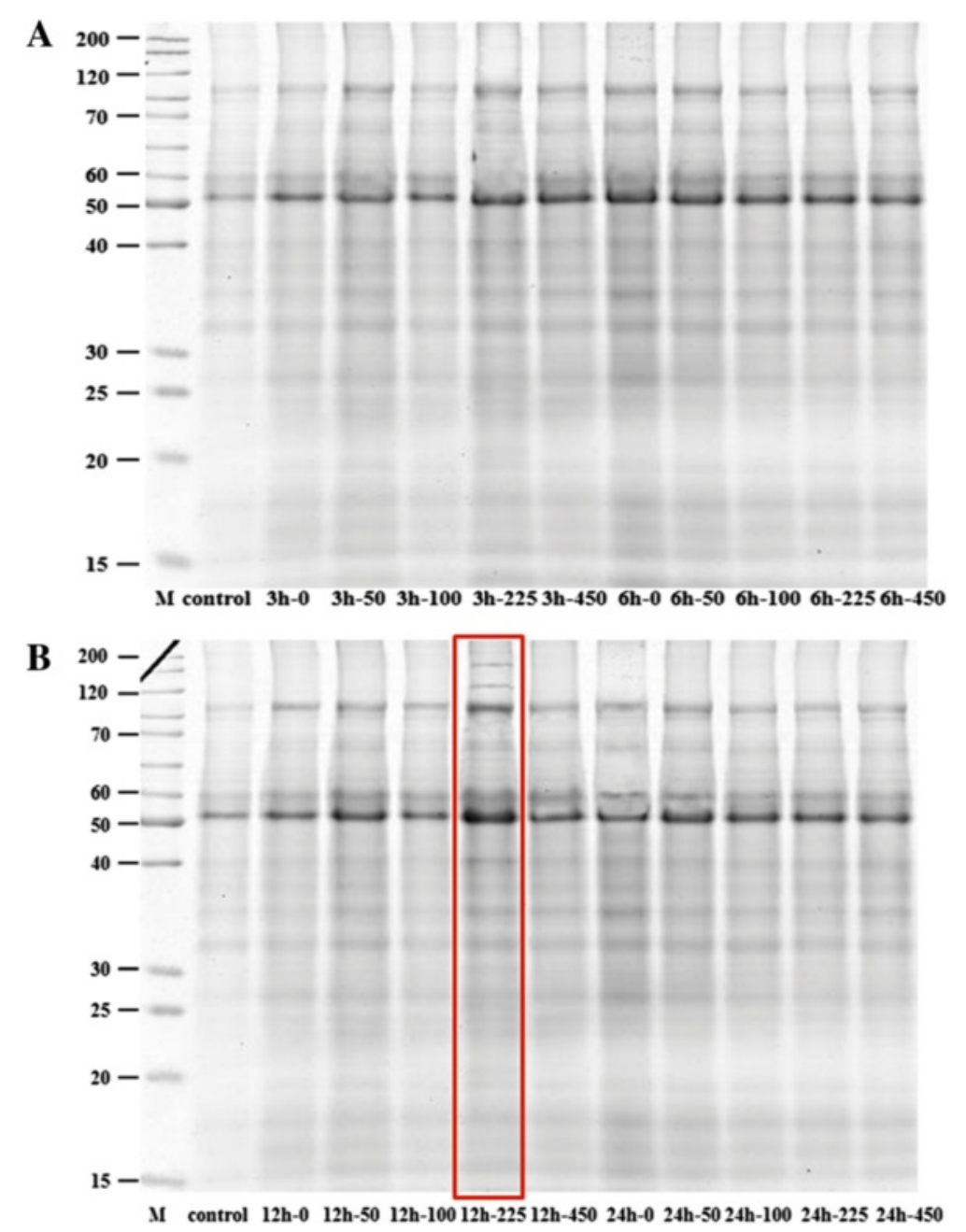

Figure 1 SDS-PAGE of proteins extracted from maize leaves after MeJA treatment. Lane M: Molecular weight marker; different lanes are labelled as treatment time ( 3 and $6 \mathrm{~h}$ in $\mathbf{A} ; 12$ and $24 \mathrm{~h}$ in $\mathbf{B}$ ) and the concentrations of MeJA $(0,50,100,225$ and $450 \mu \mathrm{M})$.

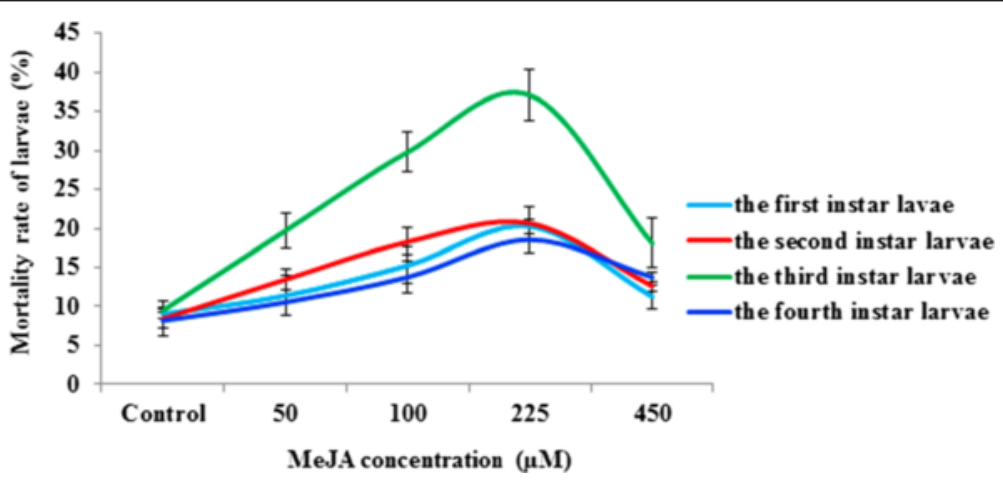

Figure 2 Lethal effects of feeding Asian corn borer larvae with MeJA-treated maize leaves. 
Table 1 Effects of different concentrations MeJA treatment on the developmental duration of different instar Asian corn borer larvae

\begin{tabular}{lllllll}
\hline MeJA $(\boldsymbol{\mu M})$ & \multicolumn{6}{l}{ Developmental duration of different stages of larvae (Days) } \\
\cline { 2 - 7 } & $\mathbf{1}^{\text {st }}$ instar & $\mathbf{2}^{\text {nd }}$ instar & $\mathbf{3}^{\text {rd }}$ instar & $\mathbf{4}^{\text {th }}$ instar & $\mathbf{5}^{\text {th }}$ instar & Total duration \\
\hline Control & $4.17 \pm 0.08 \mathrm{a}$ & $3.78 \pm 0.11 \mathrm{~b}$ & $3.96 \pm 0.03 \mathrm{c}$ & $1.99 \pm 0.05 \mathrm{~b}$ & $4.25 \pm 0.14 \mathrm{~b}$ & $18.15 \pm 0.34 \mathrm{c}$ \\
50 & $4.33 \pm 0.33 \mathrm{a}$ & $3.89 \pm 0.11 \mathrm{~b}$ & $3.97 \pm 0.12 \mathrm{c}$ & $1.93 \pm 0.23 \mathrm{~b}$ & $4.50 \pm 0.29 \mathrm{~b}$ & $18.62 \pm 0.85 \mathrm{c}$ \\
100 & $4.27 \pm 0.15 \mathrm{a}$ & $3.97 \pm 0.03 \mathrm{~b}$ & $4.33 \pm 0.09 \mathrm{bc}$ & $2.17 \pm 0.09 \mathrm{~b}$ & $4.87 \pm 0.09 \mathrm{a}$ & $19.60 \pm 0.31 \mathrm{bc}$ \\
225 & $4.83 \pm 0.17 \mathrm{a}$ & $4.67 \pm 0.17 \mathrm{a}$ & $4.83 \pm 0.12 \mathrm{a}$ & $3.50 \pm 0.25 \mathrm{a}$ & $5.72 \pm 0.43 \mathrm{a}$ & $23.56 \pm 0.24 \mathrm{a}$ \\
450 & $4.33 \pm 0.33 \mathrm{a}$ & $4.33 \pm 0.33 \mathrm{a}$ & $4.07 \pm 0.07 \mathrm{c}$ & $3.29 \pm 0.20 \mathrm{a}$ & $4.56 \pm 0.29 \mathrm{~b}$ & $20.58 \pm 0.20 \mathrm{~b}$ \\
\hline
\end{tabular}

Notes: The data are average \pm standard deviation. Different letters indicate the significant differences between treatments at $P<0.05$ (Duncan's multiple range test).

We also evaluated the effects of MeJA on the life table of ACB. Compared to the control group, When ACB larvae/adults were fed corn leaves treated with $225 \mu \mathrm{M}$ of $\mathrm{MeJA}$, the net reproductive decreased $55.6 \%$, the intrinsic rate of increase decreased $30.8 \%$, and time to double the population increased $44.4 \%$ (Table 3 ).

The proteome profile of maize leaves in response to MeJA and its functional classification

2-D gels were performed to separate proteins in two dimensions for quantitative analysis and protein identification. Quantitative image analysis by the ImageMaster ${ }^{\text {тM }}$ 2-D Platinum 7.0 revealed significant changes in 62 protein spots (Figure 4 and Additional file 1: Table S1) with a change greater than 1.5 fold $(P<0.05)$. Of the 62 MeJA-responsive proteins, 43 proteins were significantly increased, 11 were decreased, and 8 were detectable. Protein spots from both control and MeJA group were excised and identified (Additional file 2: Table S2).

The identified proteins further were classified based on their subcellular localization and biological process according to annotations in the Swiss-Prot database. All of the identified proteins were classified into 10 functional groups, covering a wide range of pathways and functions: photosynthesis (21.7\%), energy (16.7\%), protein folding, degradation, modification (15.0\%), stress and defense $(11.7 \%)$, redox-regulation $(8.3 \%)$, transcription

Table 2 Effects of different concentrations of MeJA on the life span and fecundity of adult Asian corn borers

\begin{tabular}{llll}
\hline MeJA $(\boldsymbol{\mu M})$ & $\begin{array}{l}\text { Adult life } \\
\text { span (days) }\end{array}$ & $\begin{array}{l}\text { No. of eggs laid } \\
\text { per female per day }\end{array}$ & $\begin{array}{l}\text { Adult } \\
\text { fecundity }\end{array}$ \\
\hline Control & $9.00 \pm 0.58 \mathrm{a}$ & $22.20 \pm 0.81 \mathrm{a}$ & $110.78 \pm 0.83 \mathrm{a}$ \\
50 & $8.77 \pm 0.15 \mathrm{ab}$ & $20.97 \pm 0.55 \mathrm{a}$ & $100.72 \pm 0.70 \mathrm{~b}$ \\
100 & $8.07 \pm 0.12 \mathrm{abc}$ & $19.27 \pm 0.27 \mathrm{~b}$ & $77.5 \pm 0.46 \mathrm{c}$ \\
225 & $7.67 \pm 0.28 \mathrm{c}$ & $18.60 \pm 0.16 \mathrm{~b}$ & $70.89 \pm 1.83 \mathrm{~d}$ \\
450 & $7.80 \pm 0.06 \mathrm{bc}$ & $19.14 \pm 0.21 \mathrm{~b}$ & $74.76 \pm 1.11 \mathrm{C}$ \\
\hline
\end{tabular}

Notes: The data are average \pm standard deviation. Different letters indicate the significant differences between treatments at $P<0.05$ (Duncan's multiple range test). related protein $(6.7 \%)$, metabolism (5.0\%), protein synthesis (3.3\%), secondary metabolism (1.7\%), and cell structure (1.7\%). We also found some unknown proteins $(8.3 \%)$. The four largest groups of proteins, consisting of 39 proteins, were associated with photosynthesis, energy, protein folding and defense-related proteins, which indicated that multiple cellular processes are important for plant defense responses triggered by MeJA (Figure 5).

Five heat shock-related proteins/chaperones were responsive to the MeJA treatment. Seven spots (spots 8, $11,13,31,33,34$, and 49) were increased in the presence of MeJA. Spots 8, 11, and 13 were identified to be betaD-glucosidase precursor. Spots 31 and 33 were identified to be glutathione transferases (GSTs) 5 and 19, respectively. The pathogenesis-related protein 1 was also found to respond to MeJA in this study. We found increases in two superoxide dismutase (SODs), SOD [Cu-Zn] 2 (spot 36) and SOD [Mn] 3, 4, mitochondrial precursor (spot 40). We identified GDP-mannose 3, 5-epimerase. Spot 30 was identified as dehydroascorbatereductase (DHAR) and increased after MeJA treatment. Four proteins involved in plant metabolism (spots 17, 22, 26, and 37) were increased by MeJA treatment. Spots 17, 22, and 26 play major roles in detoxification in plant secondary metabolism. Spot 17, identified as aldoketoreductase family 1, member B1, has frequently been implicated in the metabolism of exogenous and endogenous toxicants, including those stimulated by stresses [20,21]. Spot 22, identified as inorganic pyrophosphatase, was increased after MeJA treatment. MeJA treatment induced the differential expression of four translation-related spots (spots 10, 43, 44, and $50)$ in leaves. Spot 10 was identified as plasminogen activator inhibitor 1 RNA-binding protein and increased by MeJA treatment. Spots 43 and 44 were decreased and identified as nucleic acid binding protein 1 and ribonucleoprotein, respectively. Spot 14 was identified as hypothetical protein LOC100194135, containing an agglutinin domain and increased in response to MeJA treatment (Figure 4). 

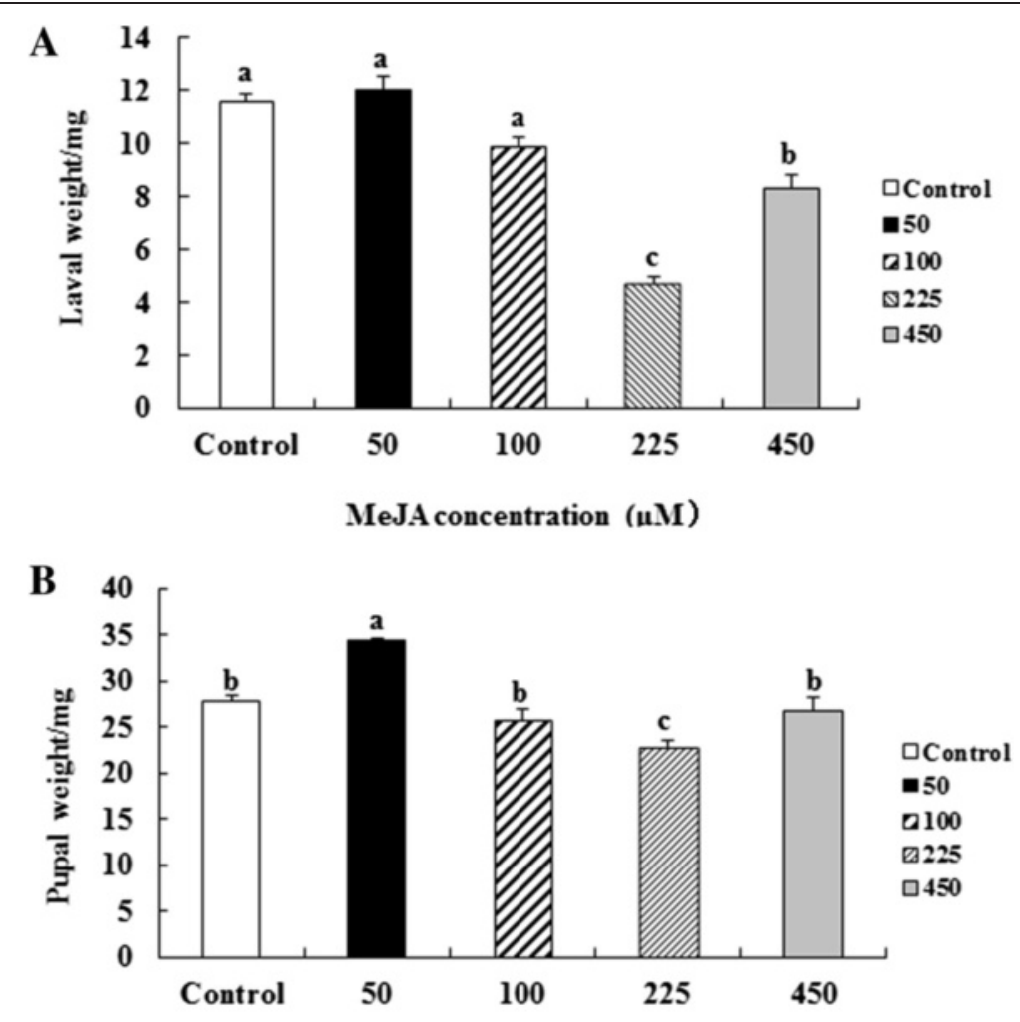

C

MeJA concentration $(\mu \mathrm{M})$
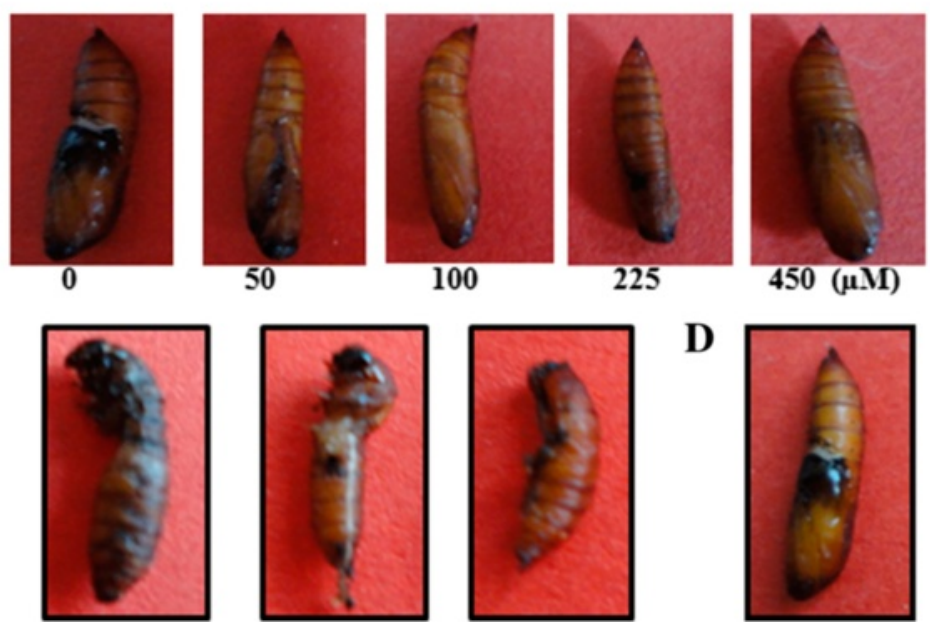

D

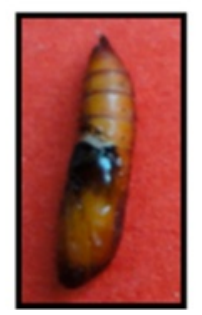

Figure 3 Effects of MeJA-induced maize leaves on the growth and development of ACB. Larval (A) or pupal (B) weight (mg) after MeJA treatment; abnormal (C) and normal (D) pupae after MeJA treatment.

Table 3 Effects of $225 \mu \mathrm{M}$ of MeJA on the life table parameters of Asian corn borer

\begin{tabular}{llllll}
\hline Treatment & $\begin{array}{l}\text { Net reproductive } \\
\text { rate }\end{array}$ & $\begin{array}{l}\text { Mean generation } \\
\text { time }\end{array}$ & $\begin{array}{l}\text { Intrinsic rate } \\
\text { of increase }\end{array}$ & $\begin{array}{l}\text { Finite rate } \\
\text { of increase }\end{array}$ & $\begin{array}{l}\text { Double population } \\
\text { time (days) }\end{array}$ \\
\hline Control & 14.81 & 37.18 & 0.0725 & 1.0752 & 9.56 \\
MeJA & 6.57 & 37.47 & 0.0502 & 1.0515 & 13.80 \\
\hline
\end{tabular}



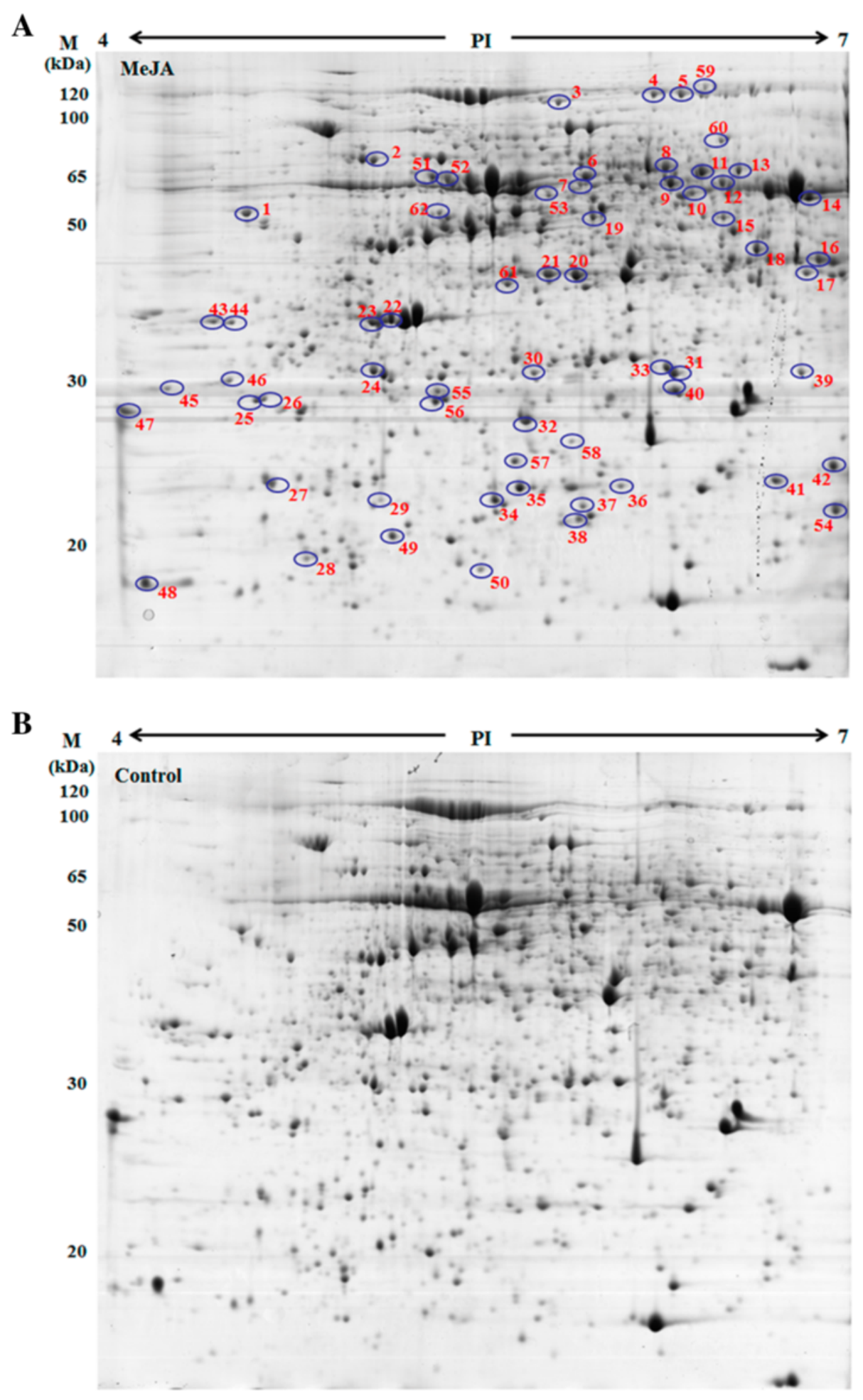

Figure 4 2-D gel analysis of proteins extracted from maize leaves treated by $225 \mu \mathrm{M}$ MeJA for 12 h. A total of $1000 \mu \mathrm{g}$ of protein was loaded on each IPG strip (PI 4-7). Protein spots were visualized using Coomassie brilliant blue staining. Protein spots from both MeJA treatment (A) and control group (B) were identified. 


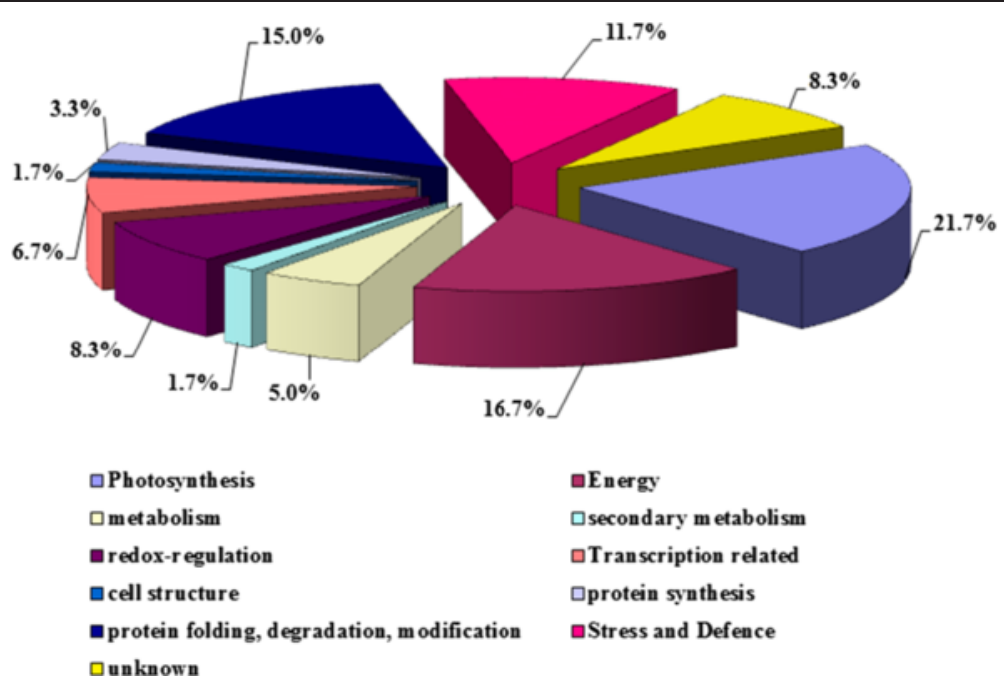

Figure 5 Functional classifications of differentially expressed proteins in response to MeJA treatment. The pie chart shows the distribution of the MeJA-responsive proteins into their functional classes in percentages.

Quantitative RT-PCR analysis of four defense genes Four genes closely associated with plant defense were selected for qRT-PCR analysis: beta-D-glucosidase precursor gene $(b g l)$; thioredoxin M-type, chloroplastic precursor gene (TRXM); pathogenesis-related protein 1 gene (PR1); and glycine-rich RNA-binding, abscisic acid-inducible protein gene (RAB15). The primers of these four genes and the reference gene (actin) are listed in Table 4. The qRT-PCR results are shown in Figure 6. The primers were designed using Primer Premier 5.0. The suitable restriction enzymes were added when we designed the primers for in-fusion defensive proteins. Following MeJA treatment, there was more than 1.5 fold increase in the expression levels of these four genes. The bgl (GenBank No. HQ834242), PR1 (GenBank No. HQ834244), and RAB15 (GenBank No. HQ834245) genes were up-regulated while TRXM (GenBank No. HQ834243) was down-regulated after MeJA induction.
Cloning and expression of four fusion proteins and evaluation of their effects on $A C B$

Genes TRXM, RAB15, PR1, and $b g l$ were cloned and the PCR products were subjected to $1 \%$ agarose electrophoresis shown in Additional file 3: Figure S2. The positive clones were screened by enzyme digestion and PCR amplification (Additional file 4: Figure S3). The induced proteins and the control were loaded on a $5 \%$ SDS-PAGE, and three fusion proteins were successfully expressed (Figure 7). The concentrations of the purified proteins PR1, TRXM, and RAB15 were tested as $1.14,1.03$, and $1.50 \mathrm{mg} / \mathrm{mL}$ by Bradford assay. We fed $\mathrm{ACB}$ with the same concentration of purified protein. Compared to $\mathrm{ddH}_{2} \mathrm{O}$ and pET-28a empty vector groups, fusion proteins of TRXM and PR1 significantly delayed the growth and development of $\mathrm{ACB}$, and the inhibition rates were $30.3 \%$ and $34.1 \%$, respectively.

Table 4 Primers of four defense genes

\begin{tabular}{|c|c|c|c|}
\hline Genes & Expressed level & Primers for qRT-PCR & Primers for expression vectors \\
\hline \multirow[t]{2}{*}{ Actin } & - & S- 5' CGGCAGCCTCCATACCAA 3' & - \\
\hline & & A - 5' GCCAAGAACAGCTCCTCA 3' & - \\
\hline \multirow[t]{2}{*}{$b g l$} & Up & S- 5' TCGCCACAAAGCAGTAAGC 3' & S- 5'gcGAGCTCATGGCTCCACTTCTCGCCGCAG3' \\
\hline & & A- 5' ACCAAAGATGAAGTCAGAGGG 3' & A - 5'cgCTCGAGAGCTGGCGTAATAATCTTCTTG3' \\
\hline \multirow[t]{2}{*}{$T R X M$} & Up & S- 5' TTGGTGATGGCGTGCGAGAC 3' & S- 5'gcGGATCCATGGCCATGGAGACGTGCTT3' \\
\hline & & A- 5' TGGATGCCGTAGGCGTCGT 3' & A - 5'cgAAGCTTTGAGCTACCGATGTACTTGT3' \\
\hline \multirow[t]{2}{*}{ PR1 } & Up & S- 5' TCGCACATCAAGGTGGAGC 3' & S- 5'gcGGATCCATGGCCTCCGTCAACAGCT3' \\
\hline & & A- 5' ATGGTTTAGTTGTAGGCGTCGG 3' & A - 5'cgAAGCTTGTTGTAGGCGTCGGGGTT3' \\
\hline \multirow[t]{2}{*}{$R A B 15$} & Down & S- 5' GAGAATGCCTTCGCCTCCTAC 3' & S- 5' gcGGATCCATGGCGGCGGCTGATGTGGAGT3' \\
\hline & & A- 5' GTCGAGCTCCTTGCCGTT 3' & A - 5'cgAAGCTTGTCCCTCCAGCCGCCGCCG3' \\
\hline
\end{tabular}

Notes: The bold sequences are restriction enzyme sites. S: upstream primers; A: downstream primers. 


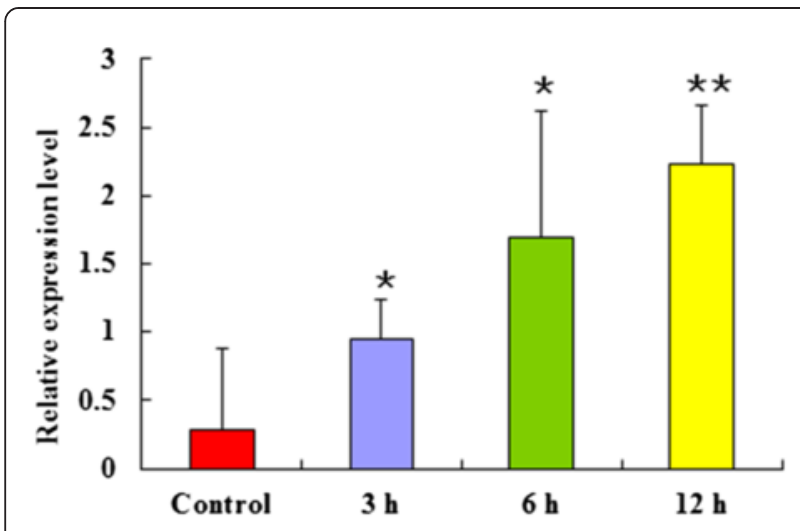

bgl: Beta-D-glucosidase percursor gene

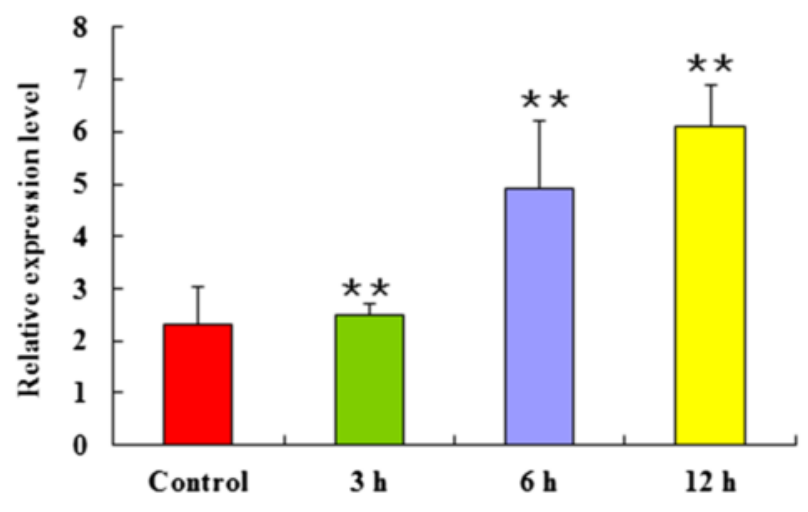

PR1: Pathogenesis-related protein I
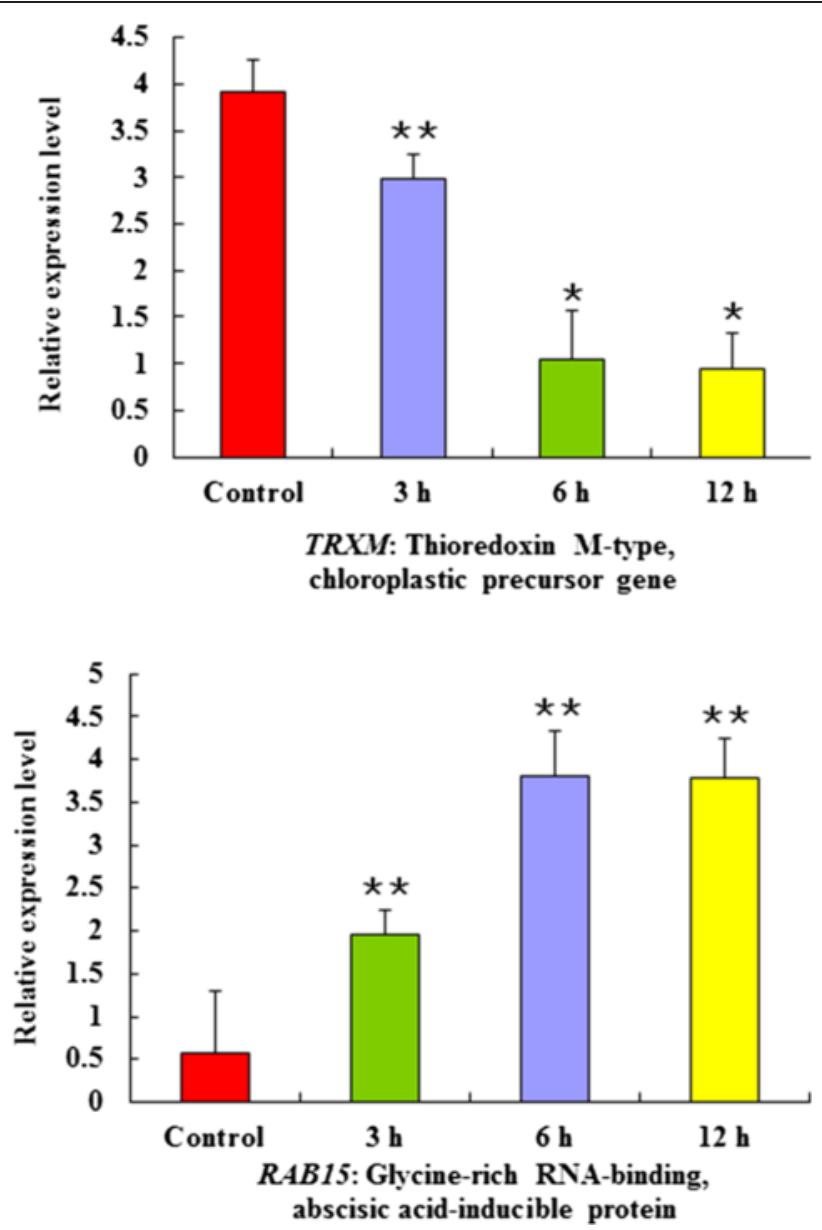

Figure 6 Quantitative RT-PCR analysis of four defense genes was performed after MeJA treatment. The chart shows the expression abundance of the selected genes' transcripts in response to MeJA treatment, ${ }^{*}$ and ${ }^{* *}$ indicate that values are significantly different at $P<0.05$ and $P<0.01$ level, respectively.

The fusion protein of RAB15 did not affect the weight of larvae but significantly affected the weight of the ACB pupae (Figure 8).

\section{Comparative analysis of transcriptome data and proteome data}

Comparing proteome data with the transcriptome data, we identified 23 genes out of the 137 genes that were matched to 26 proteins by identity or high homology (Additional file 2: Table S2). When the relative protein expression levels were compared with mRNA levels, 14 displayed similar expression trends, and 13 showed opposite trends of expression. For example, spot 50 (RAB15 protein) showed decreased protein level after induction by MeJA, while qRT-PCR showed increased level of mRNA expression. For those that followed similar up or down expression trends at the mRNA and protein levels, they differed in fold change at the two levels.

\section{A hypothetical model of MeJA response in maize}

In Figure 9, we offer a possible pathway that describes how MeJA may induce responsive proteins with insect defense capabilities. In the hypothetical model, TAB15 is viewed as central to ABA and JA signaling, and it transfers the signal to receptors to induce the expression of JA responsive defense genes for PR1- or TRXM-mediated resistant reactions. BGL protein also may involve this JA responsive defense. Thus, maize could perceive the MeJA signal to regulate transcription, protein synthesis, and related bioprocesses, thereby affecting the levels of functional proteins to defend against pathogens such as ACB. These processes work cooperatively to establish a defensive state in maize plants under attack by pathogenic herbivores.

\section{Discussion}

\section{Two-dimensional gel electrophoresis}

While 2-D gels provide information about protein quantity, charge, and mass of an intact protein, the method 


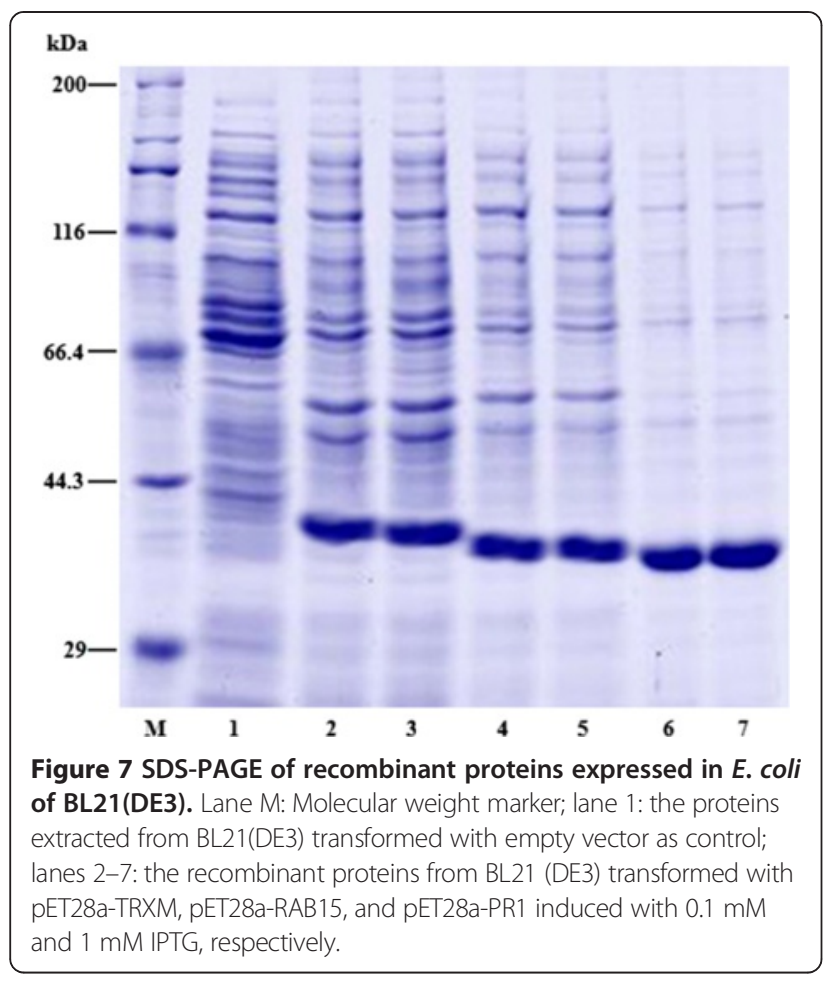

has limitations when analyzing of multiple proteins present in a single spot. Specifically, the change of the spot intensity caused by experimental treatment usually cannot be assigned to a particular protein [22]. In our study, spot 39 showed a significant 1.5 -fold increase after MeJA treatment. The two proteins identified in this spot were glutathione transferase III (a) and the hypothetical protein LOC100191154 containing a proteasome subunit alpha domain (Additional file 1: Table S1). Since the 2-D gel method has an advantage in distinguishing proteins of closely related family members and proteins with different modifications leading to changes in $\mathrm{pI}$ and molecular weight, the pattern of these protein spots on the gel may indicate possible genetic isoforms and/or post-translational modifications PTMs. The possible existence of different protein isoforms is worthy of further investigation.

Under herbivore attack, secondary metabolites such as phenolic acids, tannins, and alkaloids are produced to induce and enhance plant defense. In addition to secondary metabolites, the plant defense response is mediated by defense proteins [23]. The proteins induced by exogenous MeJA are considered to be an important "defense weapon" in plants. For example, plant protease inhibitors (PIs) induced by wounding bind protease enzymes in the insect, thereby decreasing or inhibiting protein digestion activities in the gut. The expression of PIs is regulated by a JA pathway [24]. The expression of the JA-inducible proteins (JIPs), threonine deaminase enzyme and arginase, enhance plant tolerance to herbivores $[25,26]$. The plant response to exogenous MeJA includes massive changes in physiology and biochemistry. The proteins involved in JA synthesis, regulation of cell wall structures, stress and defense responses, and photosynthesis are all induced by MeJA [27]. In this study, we have provided additional candidates for the MeJA-responsive proteome.

\section{Some important proteins in plant defense reactions Protein folding, degradation, modification-related proteins}

Heat-shock proteins (Hsps)/chaperones are responsible for protein folding, assembly, translocation, and degradation in normal cellular processes. They stabilize proteins and membranes, and assist in biotic and abiotic stress tolerance by protein refolding [28]. Thus, the ubiquitous Hsps/ chaperone system plays pivotal roles in cells under normal and stressful conditions [29]. Here we identified five heat shock-related proteins/chaperones in maize response to the MeJA treatment that also increased in abundance after MeJA treatment (Additional file 1: Table S1). As lowmolecular-mass Hsps, small Hsps (sHsps, 12-40 kDa) form a widespread and more diverse family than other Hsps/ chaperones with respect to sequence similarity, cellular location and functions [30-32]. The increased abundance of sHsps/chaperones after MeJA treatment suggests that Hsps are synthesized in plant cells in response to biotic stresses. In addition, $\mathrm{S}$-phase kinase-associated-protein 1 (SKP1), was shown to be a component of a SCF (SKP1-Cullin-Fbox) complex which is necessary for ubiquitin-mediated protein degradation in eukaryotes [33]. In Arabidopsis, many F-box proteins are found to interact with ASK1 or ASK2, which suggests that they could form various SCF complexes, and that SCF complexes may regulate plant development by affecting the signal pathways of auxin, gibberellin, and ethylene [34]. In our study, the SKP1-like protein $1 \mathrm{~A}$ increased in response to MeJA treatment in maize (Additional file 1: Table S1) which indicates that this protein may mediate the MeJA signaling pathway to enhance plant defense responses [34].

\section{Defense and stress-related proteins}

Plant responses to abiotic and biotic stresses involve the expression of a large number of proteins, many of which are believed to be crucial components of the plant's selfdefense mechanism. In this study, seven spots (spots 8 , $11,13,31,33,34$, and 49) increased in the presence of MeJA. Spots 8, 11 and 13 were identified to be a beta-Dglucosidase precursor. Beta-glucosidases play significant roles in diverse aspects of plant physiology and activate chemical defense compounds that function as a chemical deterrent to herbivore and pathogen attack [35]. In some cases, a functional diversification of glutathione transferases (GSTs) has roles in isomerization, reduction, and the binding, protection, and transport of 

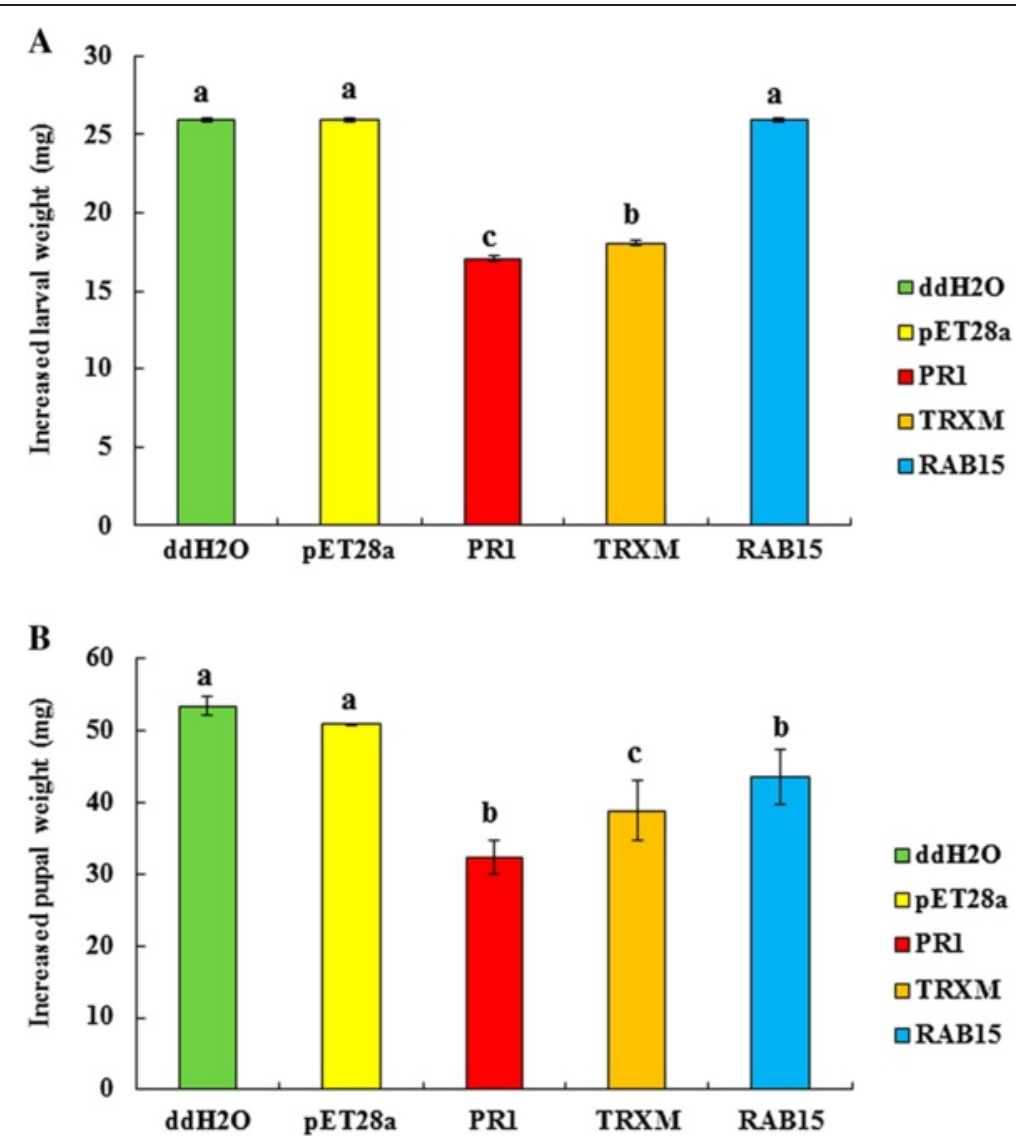

Figure 8 Effects of recombinant proteins on the larval and pupal weight of Asian corn borer. Increased larval (A) and pupal (B) weight were measured.

secondary products [36]. In this study, spots 31 and 33 were identified to be GSTs 5 and 19, respectively. Plant GSTs have been associated with responses to biotic and abiotic stress, hormones and developmental changes. Our results suggest that GSTs mediate plant defense through direct and indirect methods. We also detected the pathogenesis-related protein 1 as responsive to MeJA. This response has been observed previously in Arabidopsis, rice, and tobacco with exogenous application of JA [7-10].

\section{Redox-related proteins}

To reduce oxidative injuries induced from reactive oxygen species (ROS), plants have developed enzymatic systems for scavenging ROS [37]. Superoxide dismutase (SOD) catalyzes the conversion of the toxic $\mathrm{O}_{2}^{-}$radial to oxygen $\left(\mathrm{O}_{2}\right)$ and $\mathrm{H}_{2} \mathrm{O}_{2}$. Catalase, peroxidase, and ascorbate peroxidase (APX) can convert ROS such as $\mathrm{H}_{2} \mathrm{O}_{2}$ to water and $\mathrm{O}_{2}$. ROS work together as enzymatic antioxidant defense systems in yeasts, animals, and plants. We found an increase of two SODs (spots 36 and 40). They were SOD $[\mathrm{Cu}-\mathrm{Zn}] 2$ (spot 36 ) and SOD $[\mathrm{Mn}] 3,4$, mitochondrial precursor (spot 40). Initially discovered as regulators of light-dependent malate biosynthesis in the chloroplast [38,39], plant thioredoxins are involved in a large panel of reactions related to metabolism, defense, and development [40].

We also identified GDP-mannose 3,5-epimerase. This enzyme catalyzes a reversible epimerization of GDPD-mannose that precedes the committed step in the biosynthesis of vitamin $C$, an enzyme cofactor and an antioxidant [41]. It plays a crucial role in response to induction by MeJA in many essential physiological processes such as biosynthesis of the cell wall, phytohormones, secondary metabolites, cell division, growth, stress resistance, and photoprotection in plants [42]. Spot 30 was identified as dehydroascorbatereductase (DHAR) and increased after MeJA treatment. Expression of DHAR responsible for regenerating ascorbic acid from an oxidized state regulates the cellular redox state, which in turn affects cell response and tolerance to environmental ROS. Ascorbate is essential for the detoxification of environmental toxins and products of oxidative stress [43]. 


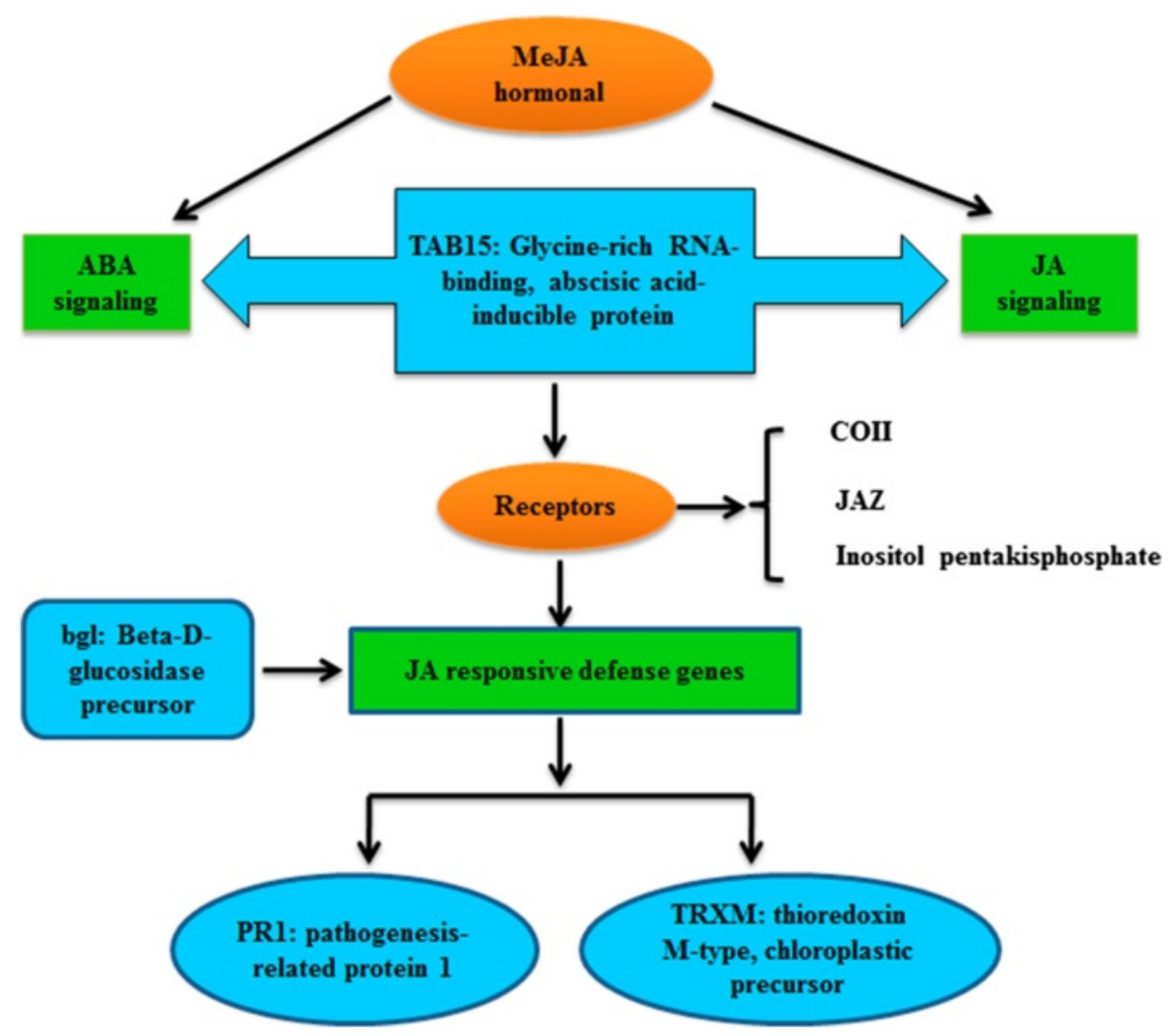

Figure 9 Hypothetical model of MeJA response in maize.

\section{Metabolism-related proteins}

In Zea mays, four proteins involved in plant metabolism (spots 17, 22, 26, and 37) were increased by MeJA treatment (Additional file 1: Table S1 and Figure 4). Spots 17,22 , and 26 play major roles in detoxification in plant secondary metabolism. Spot 17 , identified as aldoketoreductase family 1 , member B1, has frequently been implicated in the metabolism of exogenous and endogenous toxicants, including those stimulated by stresses [20,21]. Spot 22, identified as inorganic pyrophosphatase, increased after MeJA treatment. Pyrophosphoric acid in plant tissues is mainly produced in the biosynthesis of RNA, protein, carbohydrates, etc. Accumulation of pyrophosphoric acid can inhibit normal biosynthesis and affect plant growth. In plant cells, inorganic pyrophosphatase can decompose pyrophosphoric acid into inorganic pyrophosphate to detoxify and enable plant growth. On the other hand, some related studies showed that the protein coding genes were induced by ABA suggesting ABA signal conduction [44]. We deduce that the inorganic pyrophosphatase may be induced by MeJA treatment, and through the MeJA signal pathway, regulate its related gene expression.

Compared with other studies that many metabolites such as carbohydrates, lipids, protein metabolite related proteins, and secondary metabolism, related proteins induced by MeJA, we only identified a few proteins related to metabolism. This may be closely related to the treatment time and concentration of MeJA.

RNA-binding proteins (RBPs) play key roles in posttranscriptional control of RNAs, which along with transcriptional regulation, are an important way to regulate patterns of gene expression during development [45]. Nucleic acid-binding protein (NBP) belongs to a family of nuclear-encoded chloroplast proteins, which share a common domain structure and are thought to be involved in the post-transcriptional regulation of chloroplast gene expression [46]. Post-transcriptional regulation can occur at many different steps in RNA metabolism, including splicing, polyadenylation, mRNA stability, mRNA localization and translation. Our results suggest that JA treatment can regulate transcription and posttranscription of RNAs. Most importantly, we identified a glycine-rich, RNA-binding, ABA-inducible protein with decreased abundance in response to MeJA. This family of proteins is involved in the regulation of posttranscriptional gene expression processes including pre-mRNA splicing, mRNA transport, mRNA stability and translation [47-49]. It has been reported that the glycine-rich, RNA-binding, ABA-inducible protein 7 
expression is modulated via a circadian clock and by a variety of abiotic and biotic stress conditions [50]. Recently, this protein was shown to affect stomata movement in response to abiotic stress, and thus, played a role in freezing tolerance and response to dehydration under high salinity stress [51]. The glycine-rich, RNA-binding, abscisic acid-inducible protein has $82 \%$ positive homology with a protein from rice associated with disease resistance [52]. Except for complex light harvesting, proteins, microarray studies did not identify significant expression changes in genes of the other proteins, highlighting the importance of proteomic studies. Interestingly, microarray analysis showed that MeJA treatment led to remarkably decreased transcripts of ABA-responsive genes, indicating that an antagonistic interaction occurs between the JA and ABA signaling pathways in abiotic stress responses [53].

\section{Cell structure}

Spot 14, which increased response to MeJA treatment, was identified as the hypothetical protein LOC100194135 containing an agglutinin domain. It is involved in the regulation of gene expression in stressed plants through specific protein-carbohydrate interactions with regulatory cytoplasmic/nuclear glycoproteins. Many flowering plants contain sequences encoding putative homologues of the tobacco lectin-JA inducible proteins (JIPs), which imply a possible ubiquitous family of lectins with a specific endogenous role [54]. However, there is no report regarding the function of LOC100194135 and whether it belongs to JIPs. It is possible that further analysis of this protein may enhance our understanding of JIPs.

In this study, we confirmed the presence of known MeJA responsive proteins, such as GSTs, pathogenesisrelated protein 1, thioredoxin M-type (chloroplastic precursor), and a beta-D-glucosidase precursor in addition to identifying new stress and defense related proteins such as chaperone protein $\mathrm{ClpB} 1$, putative, expressed and putative small heat shock protein, $5^{\prime}$-partial and so forth. The proteins play different specific biological functions, e.g., some play major roles in plant response to stresses. At present, information about these protein functions is not complete, but their expression changes after MeJA induction will provide valuable references for us to elucidate the induced defense mechanisms.

\section{Comparative analysis of transcriptome data and proteome data}

The only available transcriptomics analysis of leaves treated by MeJA was carried out using microarrays in $A$. thaliana and in rice. Although 137 jasmonate-responsive genes were differentially expressed in A. thaliana [53], the study did not thoroughly identify the gene functions in the JA or MeJA signaling pathways.

We also found that changes of beta-D-glucosidase precursor gene and pathogenesis-related protein 1 gene were similar at the transcriptional level and the protein level. Thioredoxin M-type, chloro-plastic precursor, and glycine-rich RNA-binding, abscisic acid-inducible protein exhibited the most drastic changes at the protein level, but their expression levels were not similar to their protein abundances. The mRNA levels are not always consistent with protein levels because of various posttranscriptional, translational, and post-translational levels regulatory mechanisms [20-23].

It should also be noted that the molecular weight of fusion proteins was much higher than predicted and may be attributed to the expression vector. Some studies have shown that the His-tag strong electric charge may influence many other His-tag fusion proteins to form higher apparent molecular weight in SDS-PAGE [55].

\section{Conclusions}

In summary, we applied a 2-D gel approach to identify the proteome changes in maize in response to MeJA treatment. Proteomics analyses identified several proteins involved in stress and defense responses. These proteins may serve important roles in MeJA signal transduction by MS/MS mapping. Further analysis by qRT-PCR showed that the mRNA transcription levels did not necessarily correlate with the abundance of their corresponding proteins and highlights the importance of conducting both proteomics and transcriptome analyses.

\section{Methods}

\section{Ethics statement}

The study and protocols for collection of proteomic data and procedures were approved by all the authors' institutional and/or licensing committee, and we confirmed that all experiments were performed in accordance with relevant guidelines and regulations (Editor: Dr. Leonard Foster, University of British Columbia, Canada).

\section{Chemicals and reagents}

All the chemicals and solvents were of analytical grade. All the reagents were used without further purification. Bradford assay (Coomassie blue protein assay) was from Applygen Technologies Inc. (Beijing, China).

\section{Plant growth and MeJA treatment}

Seeds of Zea mays L. Dongnong 250 were used in this study. The seeds were sown into plastic basins $(10 \mathrm{~cm} \times$ $15 \mathrm{~cm})$ and kept at room temperature. The plants were grown at $27 \pm 1^{\circ} \mathrm{C}$ with a $14: 10$ hour (light:dark) 
photoperiod with $80 \%$ relative humidity. When the maize plants developed to the interior leaf period, they were randomized into 20 groups and control groups (10 basin/each group). Four time intervals $(3,6,12$, and 24 hours) and four concentrations (50,100, 225, and $450 \mu \mathrm{M}$ of MeJA) were selected to treat the leaves of corn. One batch of leaves was frozen in liquid nitrogen and stored at $-80^{\circ} \mathrm{C}$ for protein extraction, while the others were used for the biological activity assay on ACB. Three batches of biological replicates were collected for both control and treated samples.

\section{Effects of maize treated with MeJA on ACB}

The corn borers were maintained in the chamber at $25 \pm 2^{\circ} \mathrm{C}$ under the light:dark (14:10) and the relative humidity was kept at $70 \sim 80 \%$. The artificial diets were made according to the method of Zhou et al. [56].

To evaluate the effects of feeding $\mathrm{ACB}$ with corn leaves treated with different concentration of MeJA, we selected similar size larvae kept in a glass petri dish $(90$ $\times 15 \mathrm{~mm}$ ). For $1^{\text {st }}$ and $2^{\text {nd }}$ instar larvae, 30 were used for each treatment. For $3^{\text {rd }}$ and $4^{\text {th }}$ instar larvae, 20 were used for each treatment. The experiments were repeated at least three times. The development of all stages, weight, mortality rate, and pupation rate were recorded every day. Adults were transferred into a wide mouth bottle after emergence from pupae, fed on a cotton ball soaked with $10 \%$ sucrose water, and the fecundity was recorded every day until death.

\section{Effects on larval/pupal weight}

The $3^{\text {rd }}$ instar larvae were selected and kept for $12 \mathrm{~h}$ without food. Then, they were fed with corn leaves with or without MeJA treatment. For each experiment, 30 larvae were used and the experiment was repeated three times. Larval mass was recorded after three days, weighing was continued until the larvae pupated.

\section{Effects on the life table of $A C B$}

Pupae were fed with corn leaves treated with $225 \mu \mathrm{M}$ of MeJA. Then 20 unmated females/males (female:male $=1: 1$ ) were selected, transferred to a wide mouth bottle, and fed with $10 \%$ sucrose water. The fecundity and the adult life span (days) were recorded until all the adults died. ACB eggs were transferred to fresh corn leaves and the developmental durations, the hatching rate, the larvae duration, the pupae duration, and the adult life, etc. were recorded to construct the life table of ACB [57]. Experiments were repeated in triplicate.

\section{Protein extraction, 2-D gel, image and nanoESI MS/MS analysis}

After MeJA treatment, corn leaves were grounded into powder in liquid nitrogen. The protein was precipitated in a $10 \% \mathrm{TCA}$, cold acetone solution $(\mathrm{w} / \mathrm{v})$ containing $0.07 \%(\mathrm{v} / \mathrm{v}) \beta$-mercaptoethanol at $-20^{\circ} \mathrm{C}$ for two hours. After centrifugation at $40,000 \times \mathrm{g}$ at $4^{\circ} \mathrm{C}$ for one hour, the supernatant was discarded and the pellet was rinsed with $-20^{\circ} \mathrm{C}$ cold acetone containing $0.07 \%(\mathrm{v} / \mathrm{v}) \beta-$ mercaptoethanol. The final pellet was vacuum-dried and solubilized in $3 \mathrm{~mL}$ of $7 \mathrm{M}(\mathrm{w} / \mathrm{v})$ urea containing $2 \mathrm{M}(\mathrm{w} / \mathrm{v})$ thiourea, $40 \mathrm{mM}$ DTT, and 1\% (v/v) protease inhibitor mixture (GE Healthcare, USA) on ice for about one hour. Insoluble material was removed by centrifugation at 100,000 rpm for one hour. The protein concentration was determined using the 2-D Quant kit (GE Healthcare, USA) with BSA as a standard. Samples were frozen in liquid nitrogen and stored at $-80^{\circ} \mathrm{C}$ for further analysis.

The proteins from the control group and MeJAtreated plants were compared by using 2-D gel image analysis. The isoelectric points (pI) of the spots ranged from 4 to 7 , and the molecular mass ranged from 10 to $120 \mathrm{kDa}$. For each sample, $1 \mathrm{mg}$ total protein in $450 \mu \mathrm{L}$ rehydration buffer (7 M urea, $2 \mathrm{M}$ thiourea, 2\% CHAPS, $0.5 \%$ IPG buffer with $\mathrm{PH} 4-7$, and $0.04 \mathrm{M} \mathrm{DTT)}$ was loaded onto a $24 \mathrm{~cm}, \mathrm{pH} 4-7$ linear gradient IPG strip (GE Healthcare, USA). Isoelectric focusing was performed using an Ettan IPGphor 3 isoelectric focusing system according to the manufacturer's instruction. The focusing conditions were as follows: active rehydration was carried out at low voltage liquefied for $12 \mathrm{~h}$, followed by $300 \mathrm{~V}$ for $1 \mathrm{~h}, 600 \mathrm{~V}$ for $1 \mathrm{~h}, 1000 \mathrm{~V}$ for $1 \mathrm{~h}$, with a linear increase of voltage to $8,000 \mathrm{~V}$ for $12 \mathrm{~h}$ at $20^{\circ} \mathrm{C}$. The voltage was held at $10,000 \mathrm{~V}$ until the total voltage hours reached 80,000 . After IEF, the strips were equilibrated with an equilibration solution (50 mM Tris with $\mathrm{pH} 8.8,6 \mathrm{M}$ urea, 30\% glycerol, 1\% DTT, and 2\% SDS) followed by $2.5 \%$ iodoacetamide in the equilibration solution, each for $15 \mathrm{~min}$. The second dimension was performed on $12.5 \%$ polyacrylamide gels using an Ettan DALT Six Electrophoresis Unit (GE Healthcare, USA) according to the manufacturer's instructions. The 2-D gel electrophoresis experiments were repeated three times using protein samples prepared independently from MeJA treated and control maize.

Proteins were visualized by Coomassie brilliant blue R250 and gel images were acquired using an ImageScanner (GE Healthcare, USA). Replicate gels from control and MeJA treatment were analyzed with ImageMaster 2-D Platinum Software Version 7.0 (Amersham Biosciences, USA). Experimental molecular weight $(\mathrm{kDa})$ of each protein was estimated by comparison with the protein markers, and experimental isoelectric points were determined by its migration on the IPG strip. The abundance of each protein spot was estimated by the percentage volume (\%vol). Only those spots with significant and reproducible changes were considered 
to be differentially expressed proteins. The normalized volumes of the spots from replicate gels were subjected to student's ANOVA test $(P<0.05)$ and only statistically significant data were considered. Protein in-gel tryptic digestion and nanoESI MS/MS analysis were carried out on a QSTAR XL MS/MS system (AB Sciex Inc., USA) as previously described [58]. The peptide MS/MS spectra were searched against an NCBI non-redundant fasta database $(8,224,370$ entries, June 20,2014$)$ using Mascot search engine (http://www.matrixscience.com). Mascot was set up to search green plants only, assume trypsin digestion and one allowed miscleavage. The mass tolerance for both parent ion and fragment ion mass was set to be $0.2 \mathrm{Da}$. Iodoacetamide derivatization of Cys, deamidation of Asn and Gln, and oxidation of Met were specified as variable modifications. Unambiguous identification was judged by the number of peptides, sequence coverage, Mascot score and the quality of MS/ MS spectra (Additional file 5: Figure S1) [58].

\section{qRT-PCR}

Maize leaves treated by MeJA for different periods ( 6 and $12 \mathrm{~h}$ ) and the control leaves were harvested. Total RNA was extracted using Invitrogen kit and reverse transcribed with a PrimeScript RT Reagent kit (TaKaRa, Japan) according to the manufacturers' instructions. qRT-PCR assays were performed using ABI7500 (Applied Biosystems, USA) and actin (GenBank accession number X97726) was used as an internal standard gene. Diluted aliquots of the reverse transcribed cDNAs were used as templates in RT-PCRs containing the SYBR Green PCR Master Mix (SYBR Green Real Time PCR Kit, HaiGene, China). Primers are listed in Table 4. qRTPCRs were performed with an initial activation step of the DNA polymerase at $94^{\circ} \mathrm{C}$ for $5 \mathrm{~min}$, followed by 40 cycles of $94^{\circ} \mathrm{C}$ for $12 \mathrm{~s}, 58^{\circ} \mathrm{C}$ for $30 \mathrm{~s}, 72^{\circ} \mathrm{C}$ for $40 \mathrm{~s}$, $79^{\circ} \mathrm{C}$ for $1 \mathrm{~s}$, and a step of plate reading. Triplicate reactions were carried out for each sample to ensure reproducibility. Negative controls only contained genespecific primer pairs. At the end of each PCR program, a melting curve was generated and analyzed with Dissociation Curves Software (ABI 7500 Software v2.0, USA). The length and specificity of PCR products were verified by agarose gel electrophoresis. Gene expression was quantified using the comparative cycle threshold (Ct) method [59-61].

\section{Cloning and expression of four fusion proteins and evaluation of their effects on corn borer}

To identify the TRXM, TAB15, PR1, and $b g l$ genes in maize, total RNA was extracted from the leaves using TRIzol regent (Invitrogen, USA) and RT-PCR was performed using a PrimeScript RT Reagent kit (TaKaRa, Japan) according to the respective manufacturer's instructions. The full-length coding regions of these four genes' cDNA were amplified by PCR using gene-specific primers containing NdeI and HindIII, or SacI and XhoI restriction enzyme sites (Table 4). The amplified fragments were inserted into pMD19-T vector (TaKaRa, Japan) and transformed into Escherichia coli $\mathrm{DH} 5 \alpha$, and then cultured in LB liquid medium in a rotary shaker for 12-16 $\mathrm{h}$. The cells were harvested by centrifugation and used for plasmid extraction. Full-length cDNA sequences of these four genes were confirmed by restriction digestion and DNA sequencing.

The amplified four genes were digested with the restriction enzymes (NdeI and HindIII, or SacI and $X h o I)$, and ligated into pET-28a doubly digested with the same enzymes. The recombinant plasmids were named as pET28a-TRXM, pET28a-RAB15, pET28a-PR1, and pET28a-BGL, which could produce the TRXM, RAB15, PR1, and BGL fusion protein, respectively. The correct expression vectors were verified by diagnostic restriction digestion and DNA sequencing. The correct plasmids were then transformed into $E$. coli strain of BL21 (DE3), and the bacteria were grown overnight at $37^{\circ} \mathrm{C}$ in $100 \mathrm{ml} \mathrm{LB}$ broth with $100 \mu \mathrm{g} / \mathrm{mL}$ ampicillin. The overnight culture was inoculated to one liter of fresh LB medium and was grown at $28^{\circ} \mathrm{C}$ with shaking at $250 \mathrm{rpm}$. When the $\mathrm{OD}_{600}$ of the culture reached 0.6, $0.1 \mathrm{mM}$ IPTG was added to induce the expression of protein and then made the culture grown at $25^{\circ} \mathrm{C}$. After an additional four to five hour cultivation, the cells were harvested by centrifugation at $6000 \times \mathrm{g}$ for $10 \mathrm{~min}$. The bacterial pellets were resuspended in $10 \mathrm{ml}$ of cell lysis buffer $(25 \mathrm{mM}$ Tris, $200 \mathrm{mM} \mathrm{NaCl}, \mathrm{pH} 8.0,1 \mathrm{mM}$ PMSF) and were lysed by sonication and centrifuged at $15000 \times \mathrm{g}$ for $10 \mathrm{~min}$. The supernatant was collected. His-tagged proteins were purified under native condition with His spinTrap columns as described in the manual (GE Healthcare, USA). The columns were equilibrated with PBS binding buffer with $20 \mathrm{mM}$ imidazole. The samples were loaded at a concentration of $750 \mathrm{mg} / \mathrm{mL}$. The columns were washed using PBS washing buffer with $100 \mathrm{mM}$ imidazole for five times. The in-fusion proteins were eluted using PBS elution buffer with $500 \mathrm{mM}$ imidazole.

The $3^{\text {rd }}$ instar larvae of ACB were selected to evaluate the effects of fusion proteins on their growth and development. The feeding assay was performed after the larvae were starved for 12 hour with 3 replications and 20 larval in each replicate. The empty vector and $\mathrm{ddH}_{2} \mathrm{O}$ were used as controls. The artificial diets mixed with recombinant proteins were replenished daily. Food consumption, movement and general morphology of larvae were recorded daily. After seven days, the weight of larvae and pupae were measured. The feeding assays were continued until all the larvae became pupae. Then the weight of pupae was measured. 


\section{Data analysis}

All the data were analyzed by SPSS17.0 statistical software (SPSS Inc., Chicago, IL, USA).

\section{Additional files}

\section{Additional file 1: Detailed information of comparative analysis of microarray data and proteome data by homology BLAST. \\ Additional file 2: Detailed information of identified proteins and their relative expression levels in Zea mays.}

Additional file 3: Clones of the four defense genes. Lane $M_{2}$ : DL2000 DNA marker, lanes 1-4: PCR amplification of four defense genes (TRXM, $507 \mathrm{bp} ; R A B 15, \sim 470 \mathrm{bp} ;$ PR1, 482 bp; bgl, 1692 bp).

Additional file 4: Identification of the recombination plasmids. A: Lane $M_{1}$ : DL15000 DNA marker; lane $M_{2}$ : DL2000 DNA marker; lanes 1 and 4 : single digestion of the recombination plasmids of pET28a-PR1 and pET28a-RAB15, respectively; lanes 2 and 3: double digestion of the recombination plasmids of PET28a-PR1 and PET28a-RAB15. B: Iane 1: the plasmid of pET28a; lane 2: single digestion of the recombinant plasmid of PET28a-BGL; lane 3: double digestion of the recombinant plasmid of pET28a-BGL.

Additional file 5: MS/MS spectra of two peptides. A beta-D-glucosidase (A) and a pathogenesis-related protein 1 (B) were identified from Zea mays. The $b$ and $y$ ion series were manually inspected, and the ion scores and the ranking in the Mascot search were considered.

\section{Abbreviations}

JA: Jasmonic acid; MeJA: Methyl jasmonate; ACB: Asian corn borer; 2-D gel: Two dimensional gel electrophoresis; pl: Isoelectric points; RuBisCO: Ribulose-1, 5-bisphosphate carboxylase/oxygenase; bgl: beta-D-glucosidase precursor gene; TRXM: Thioredoxin M-type, chloroplastic precursor gene; PR1: Pathogenesis-related protein 1 gene; RAB15: Glycine-rich RNA-binding, abscisic acid-inducible protein gene; IPG: Immobilized pH gradient; GST: Glutathione transferases; SCF: SKP1-Cullin-F-box; SKP1: S-phase kinase-associated-protein 1; ROS: Reactive oxygen species; SOD: Superoxide dismutase; APX: Ascorbate peroxidase; DHAR: Dehydroascorbate reductase; RBPs: RNA-binding proteins; NBP: Nucleic acid-binding protein; JIPs: JA inducible proteins.

\section{Competing interests}

The authors declared that they have no competing interests.

\section{Authors' contributions}

YTZ and YLZ performed the research; YTZ, YLZ, SXC, GHY, ZZY, CGL, DDZ, YKM and FQS contributed to the data collection and MS analysis; FSY and GHY designed the research; YTZ, YLZ, SL, FSY, GHY, and JWB wrote the paper. All authors read and approved the final manuscript.

\section{Acknowledgements}

The work was partly supported by the grant from Heilongjiang Provincial Department of Education "Research Projects of Overseas Scholars (1154hz10)".

\footnotetext{
Author details

${ }^{1}$ Key Laboratory of Molecular Biology of Heilongjiang Province, College of Life Sciences, Heilongjiang University, Harbin 150080, China. ${ }^{2}$ Key Laboratory of Biology and Genetic Resources of Tropical Crops, Ministry of Agriculture, Institute of Tropical Bioscience and Biotechnology, Chinese Academy of Tropical Agricultural Sciences, Haikou, Hainan 571101, China. ${ }^{3}$ Majorbio Pharm Technology Co., Ltd., Shanghai 201203, China. ${ }^{4}$ Department of Biology, Genetics Institute, Plant Molecular and Cellular Biology Program, Interdisciplinary Center for Biotechnology Research, University of Florida, Gainesville, Florida 32610, USA. ${ }^{5}$ Department of Plant Biology and Pathology, Rutgers, The State University of New Jersey, New Brunswick, NJ 08901, USA. ${ }^{6}$ Institute of Pesticide Science, Hunan Agricultural University, Changsha, China. ${ }^{7}$ Engineering Research Center of Agricultural Microbiology Technology, Ministry of Education, Heilongjiang University, Harbin 150500, China.
}

Received: 2 October 2014 Accepted: 19 February 2015

Published online: 21 March 2015

\section{References}

1. Creelman RA, Tierney ML, Mullet JE. Jasmonic acid methyl jasmonate acumulate in wounded soybean hypocotyls and modulate wound gene-expression. Proc Natl Acad Sci USA. 1992;89(11):4938-41.

2. Creelman RA, Mullet JE. Jasmonic acid distribution and action in plants: regulation during development and response to biotic and abiotic stress. Proc Natl Acad Sci USA. 1995;92(10):4114-9.

3. Koo AJ, Gao X, Jones AD, Howe GA. A rapid wound signal activates the systemic synthesis of bioactive jasmonates in Arabidopsis. Plant J. 2009;59(6):974-86

4. Avanci NC, Luche DD, Goldman GH, Goldman MH. Jasmonates are phytohormones with multiple functions, including plant defense and reproduction. Genet Mol Res. 2010;9(1):484-505.

5. Vijayan P, Shockey J, Levesque CA, Cook RJ, Browse J. A role for jasmonate in pathogen defense of Arabidopsis. Proc Natl Acad Sci USA. 1998;95(12):7209-14.

6. Jones JD, Dangl JL. The plant immune system. Nature. 2006;444(7117):323-9.

7. Strassner J, Schaller F, Frick UB, Howe GA, Weiler EW, Amrhein N, et al. Characterization and CDNA-microarray expression analysis of 12-oxophytodienoate reductases reveals differential roles for octadecanoid biosynthesis in the local versus the systemic wound response. Plant J. 2002;32(4):585-601.

8. Narusaka Y, Narusaka M, Seki M, Ishida J, Nakashima M, Kamiya A, et al. The cDNA Microarray analysis using an Arabidopsis pad3 mutant reveals the expression profiles and classification of genes induced by Alternaria brassicicola attack. Plant Cell Physiol. 2003;44(4):377-87.

9. Sasaki-Sekimoto Y, Taki N, Obayashi T, Aono M, Matsumoto F, Sakurai N, et al. Coordinated activation of metabolic pathways for antioxidants and defence compounds by jasmonates and their roles in stress tolerance in Arabidopsis. Plant J. 2005;44(4):653-68.

10. Heidel AJ, Baldwin IT. Microarray analysis of salicylic acid- and jasmonic acid-signalling in responses of Nicotiana attenuata to attack by insects from multiple feeding guilds. Plant Cell Environ. 2004;27(11):1362-73.

11. Agrawal GK, Yonekura M, Iwahashi Y, Iwahashi H, Rakwal R. System, trends and perspectives of proteomics in dicot plants. Part III: unraveling the proteomes influenced by the environment, and at the levels of function and genetic relationships. J Chromat B. 2005;815(1-2):137-45.

12. Agrawal GK, Jwa NS, Iwahashi Y, Yonekura M, Iwahashi H, Rakwal R. Rejuvenating rice proteomics: facts, challenges, and visions. Proteomics. 2006;6(20):5549-76.

13. Jwa NS, Agrawal GK, Tamogami S, Yonekura M, Han O, Iwahashi H, et al. Role of defense/stress-related marker genes, proteins and secondary metabolites in defining rice self-defense mechanisms. Plant Physiol Biochem. 2006;44(5-6):261-73.

14. Cho K, Agrawal GK, Shibato J, Jung YH, Kim YK, Nahm BH, et al. Survey of differentially expressed proteins and genes in jasmonic acid treated rice seedling shoot and root at the proteomics and transcriptomics levels. J Proteome Res. 2007;6(9):3581-603.

15. Duan ZB, Lv GZ, Shen CC, Li QY, Qin Z, Niu JS. The role of jasmonic acid signalling in wheat (Triticum aestivum L.) powdery mildew resistance reaction. Eur J Plant Pathol. 2014;140(1):169-83.

16. Pandey A, Chakraborty S, Datta A, Chakraborty N. Proteomics approach to identify dehydration responsive nuclear proteins from chickpea (Cicer arietinum L.) Mol Cell Proteomics. 2008;7(1):88-107.

17. Shen Z, Li P, Ni RJ, Ritchie M, Yang CP, Liu GF, et al. Label-free quantitative proteomics analysis of etiolated maize seedling leaves during greening. Mol Cell Proteomics. 2009;8(11):2443-60.

18. Imin N, Kerim T, Weinman JJ, Rolfe BG. Low temperature treatment at the young microspore stage induces protein changes in rice anthers. Mol Cell Proteomics. 2006:5(2):274-92.

19. Vizcaino JA, Deutsch EW, Wang R, Csordas A, Reisinger F, Rios D, et al. ProteomeXchange provides globally coordinated proteomics data submission and dissemination. Nat Biotechnol. 2014;32(3):223-6.

20. Jez JM, Flynn TG, Penning TM. A new nomenclature for the aldo-keto reductase superfamily. Biochem Pharmacol. 1997;54(6):639-47.

21. Simpson PJ, Tantitadapitak C, Reed AM, Mather OC, Bunce CM, White SA, et al. Characterization of two novel aldo-keto reductases from Arabidopsis: expression patterns, broad substrate specificity, and an open active-site structure suggest a role in toxicant metabolism following stress. J Mol Biol. 2009;392(2):465-80. 
22. Chen $\mathrm{S}$, Harmon AC. Advances in plant proteomics. Proteomics. 2006;6(20):5504-16.

23. War AR, Paulraj MG, Ahmad T, Buhroo AA, Hussain B, Ignacimuthu S, et al. Mechanisms of plant defense against insect herbivores. Plant Signal Behav. 2012;7(10):1306-20.

24. Farmer EE, Ryan CA. Interplant communication: airborne methyl jasmonate induces synthesis of proteinase inhibitors in plant leaves. Proc Natl Acad Sci USA. 1990:87(19):7713-6.

25. Browse J, Howe GA. New weapons and a rapid response against insect attack. Plant Physiol. 2008;146(3):832-8.

26. Chen H, Gonzales-Vigil E, Wilkerson CG, Howe GA. Stability of plant defense proteins in the gut of insect herbivores. Plant Physiol. 2007;143(4):1954-67.

27. Qureshi MI, Qadir S, Zolla L. Proteomics-based dissection of stress-responsive pathways in plants. J Plant Physiol. 2007;164(10):1239-60.

28. Haslbeck M. Recombinant expression and in vitro refolding of the yeast small heat shock protein Hsp42. Int J Biol Macromol. 2006:38(2):107-14.

29. Timperio AM, Egidi MG, Zolla L. Proteomics applied on plant abiotic stresses: role of heat shock proteins (HSP). J Proteome. 2008;71(4):391-411.

30. Boston RS, Viitanen PV, Vierling E. Molecular chaperones and protein folding in plants. Plant Mol Biol. 1996;32(1-2):191-222.

31. Soto A, Allona I, Collada C, Guevara MA, Casado R, Rodriguez-Cerezo E, et al. Heterologous expression of a plant small heat-shock protein enhances Escherichia coli viability under heat and cold stress. Plant Physiol. 1999;120(2):521-8

32. Wei Z, Hu W, Lin Q, Cheng X, Tong M, Zhu L, et al. Understanding rice plant resistance to the Brown Planthopper (Nilaparvata lugens): a proteomic approach. Proteomics. 2009:9(10):2798-808.

33. Devoto A, Nieto-Rostro M, Xie D, Ellis C, Harmston R, Patrick E, et al. COI1 links jasmonate signalling and fertility to the SCF ubiquitin-ligase complex in Arabidopsis. Plant J. 2002;32(4):457-66.

34. Li C, Liang Y, Chen C, Li J, Xu Y, Xu Z, et al. Cloning and expression analysis of TSK1, a wheat SKP1 homologue, and functional comparison with Arabidopsis ASK1 in male meiosis and auxin signalling. Funct Plant Biol. 2006;33(4):381.

35. Morant AV, Jorgensen $K$, Jorgensen C, Paquette SM, Sanchez-Perez R, Moller BL, et al. Beta-Glucosidases as detonators of plant chemical defense. Phytochemistry. 2008;69(9):1795-813.

36. Sappl PG, Carroll AJ, Clifton R, Lister R, Whelan J, Harvey Millar A, et al. The Arabidopsis glutathione transferase gene family displays complex stress regulation and co-silencing multiple genes results in altered metabolic sensitivity to oxidative stress. Plant J. 2009;58(1):53-68.

37. Park DS, Lee SK, Lee JH, Song MY, Song SY, Kwak DY, et al. The identification of candidate rice genes that confer resistance to the brown planthopper (Nilaparvata lugens) through representational difference analysis. Theor Appl Genet. 2007;115(4):537-47.

38. Hartman H, Syvanen M, Buchanan BB. Contrasting evolutionary histories of chloroplast thioredoxins f and m. Mol Biol Evol. 1990;7(3):247-54.

39. Lemaire SD, Michelet L, Zaffagnini M, Massot V, Issakidis-Bourguet E. Thioredoxins in chloroplasts. Curr Genet. 2007:51(6):343-65.

40. Meyer Y, Reichheld JP, Vignols F. Thioredoxins in Arabidopsis and other plants. Photosynth Res. 2005;86(3):419-33.

41. Wolucka BA, Van Montagu M. GDP-mannose 3',5'-epimerase forms GDP-L-gulose, a putative intermediate for the de novo biosynthesis of vitamin C in plants. J Biol Chem. 2003;278(48):47483-90.

42. Smirnoff N, Wheeler GL. Ascorbic acid in plants: biosynthesis and function. Crit Rev Biochem Mol Biol. 2000;35(4):291-314.

43. Chen Z, Young TE, Ling J, Chang SC, Gallie DR. Increasing vitamin C content of plants through enhanced ascorbate recycling. Proc Natl Acad Sci USA 2003;100(6):3525-30.

44. Fukuda A, Tanaka Y. Effects of ABA, auxin, and gibberellin on the expression of genes for vacuolar $\mathrm{H}+-$ inorganic pyrophosphatase, $\mathrm{H}+-$ ATPase subunit $\mathrm{A}$, and $\mathrm{Na}+\mathrm{H}+$ antiporter in barley. Plant Physiol Biochem. 2006:44(5-6):351-8.

45. Sawicka K, Bushell M, Spriggs KA, Willis AE. Polypyrimidine-tract-binding protein: a multifunctional RNA-binding protein. Biochem Soc Trans. 2008;36(Pt 4):641-7.

46. Licatalosi DD, Darnell RB. RNA processing and its regulation: global insights into biological networks. Nat Rev Genet. 2010;11(1):75-87.

47. Dreyfuss G, Matunis MJ, Pinol-Roma S, Burd CG. hnRNP proteins and the biogenesis of mRNA. Annu Rev Biochem. 1993;62:289-321.
48. Higgins CF. Stability and degradation of mRNA. Curr Opin Cell Biol. 1991;3(6):1013-8.

49. Simpson GG, Filipowicz W. Splicing of precursors to mRNA in higher plants: mechanism, regulation and sub-nuclear organisation of the spliceosomal machinery. Plant Mol Biol. 1996;32(1-2):1-41.

50. Staiger D, Zecca L, Wieczorek Kirk DA, Apel K, Eckstein L. The circadian clock regulated RNA-binding protein AtGRP7 autoregulates its expression by influencing alternative splicing of its own pre-mRNA. Plant J. 2003;33(2):361-71.

51. Kim JS, Jung HJ, Lee HJ, Kim KA, Goh CH, Woo Y, et al. Glycine-rich RNA-binding protein 7 affects abiotic stress responses by regulating stomata opening and closing in Arabidopsis thaliana. Plant J. 2008:55(3):455-66

52. Consortia RCaS. The sequence of rice chromosomes 11 and 12, rich in disease resistance genes and recent gene duplications. BMC Biol. 2005;3:20.

53. Jung C, Lyou SH, Yeu S, Kim MA, Rhee S, Kim M, et al. Microarray-based screening of jasmonate-responsive genes in Arabidopsis thaliana. Plant Cell Rep. 2007;26(7):1053-63.

54. Chen $Y$, Peumans WJ, Hause B, Bras J, Kumar M, Proost $P$, et al. Jasmonic acid methyl ester induces the synthesis of a cytoplasmic/ nuclear chito-oligosaccharide binding lectin in tobacco leaves. FASEB J. 2002:16(8):905-7.

55. Terpe K. Overview of tag protein fusions: from molecular and biochemical fundamentals to commercial systems. Appl Microbiol Biotechnol. 2003:60(5):523-33.

56. Zhou DR, Wang YY, Liu BL, Ju ZL. Asian corn borer artificial feeding research: I. A semi-artificial diet and improvement. Acta Phytophylacica Sinica. 1980(2)

57. Li DX, Wang HW, Wang JY, Kang ZK, Dong JF, Shen ZR. Life tables of the laboratory population of the peach fruit borer, Carposina sasakii Matsumura at different temperatures. Acta Entomol Sin. 2010;53(7):773-9.

58. Sheffield J, Taylor N, Fauquet C, Chen S. The cassava (Manihot esculenta Crantz) root proteome: protein identification and differential expression. Proteomics. 2006;6(5):1588-98.

59. Rajeevan MS, Ranamukhaarachchi DG, Vernon SD, Unger ER. Use of real-time quantitative PCR to validate the results of CDNA array and differential display PCR technologies. Methods. 2001;25(4):443-51.

60. Yin G, Sun Z, Liu N, Zhang L, Song Y, Zhu C, et al. Production of double-stranded RNA for interference with TMV infection utilizing a bacterial prokaryotic expression system. Appl Microbiol Biotechnol. 2009;84(2):323-33.

61. Wang $H$, Yin $G, Y u C H$, Wang $Y$, Sun ZL. Inhibitory effect of sanguinarine on PKC-CPI-17 pathway mediating by muscarinic receptors in dispersed intestinal smooth muscle cells. Res Vet Sci. 2013;95(3):1125-33.

\section{Submit your next manuscript to BioMed Central and take full advantage of:}

- Convenient online submission

- Thorough peer review

- No space constraints or color figure charges

- Immediate publication on acceptance

- Inclusion in PubMed, CAS, Scopus and Google Scholar

- Research which is freely available for redistribution 